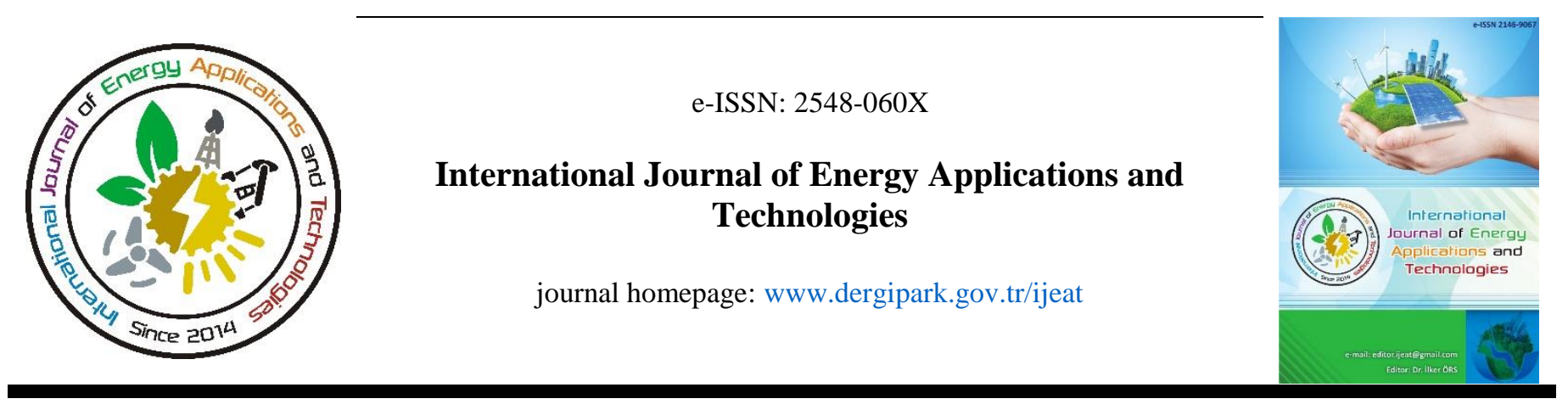

Original Research Article

\title{
Design and analysis of PV fed SRM system
}

\author{
Serhat Berat Efe ${ }^{1, *}$, Dilan Demir Aktaş ${ }^{2}$ \\ ${ }^{1}$ Department of Electrical and Electronics Engineering, Faculty of Engineering, Bitlis ErenUniversity, Bitlis, Turkey \\ ${ }^{2}$ Msc. Student, Department of Electrical and Electronics Engineering, Faculty of Engineering, Bitlis ErenUniversity, Bitlis, Turkey
}

\author{
ARTICLE INFO \\ * Corresponding author \\ s.beratefe@gmail.com \\ Received July 6, 2018 \\ Accepted September 1, 2018 \\ Published by Editorial Board \\ Members of IJEAT \\ (C) This article is distributed by \\ Turk Journal Park System under \\ the CC 4.0 terms and conditions.
}

\begin{abstract}
Renewable energy sources supplied motor applications are being studied widely by researchers. As it is especially focused on design and control of such systems, studies on performance analysis approach is limited. It is vital to determine the operating behaviour of motor loads when they are supplied by limited energy sources like photovoltaic (PV) systems. According to this necessity, in this study, a switched reluctance motor (SRM) which is supplied by a PV system is analysed in terms of speed, current and torque data. Because of its advantages as it can be controlled over a wide range, its reliability and stability, SRM was used for analysis. Such data are observed in two cases, PV system irradiance change and fault conditions. System is designed as direct-fed, which is not include any storage unit. Therefore, any changes at supply system directly affect motor parameters. These effects and results are discussed by using the graphs that obtained from various points of system for both cases.
\end{abstract}

Keywords: Switched reluctance motor, photovoltaic system, renewable energy, MATLAB

\section{Introduction}

Because of rapid increment at energy demand, it is necessary to integrate renewable energy sources as photovoltaic (PV) systems to conventional generating units to meet this issue. As such systems have limited capacity of energy generation, it is vital to analyse load characteristics in detail for using the generated energy most efficient. In addition, it is important to determine properties and operational performance of load while supplied by a renewable energy source.

PV generating reaches to $100 \mathrm{GW}$ by 2018 around the world. As it is the most preferred renewable energy source, PV systems are studied widely in literature. The recent studies are varies among design [1-3], analysis [4] and grid integration [5-8] issues. These studies are both on single phase and three phase systems. Researchers were investigated such systems in detail in terms of efficiency and control in these studies.
Similar as this study, there are also valuable works on PV supplied motor applications. These applications vary on large industrial systems. While the most of these studies are focused on the water pumping systems [9-13], especially for agricultural applications, researchers also investigated control techniques and performances of systems with motor loads used in other residential and industrial areas [14-17]. Because of their advantages like to be used in a very large speed range, also developments in control systems, in recent years switched reluctance motors (SRMs) take a valuable place in these studies.

In this paper, a SRM that is energized by a PV system is analysed. According to this aim, a system that consist of SRM, which is supplied by a PV system is designed under MATLAB / Simulink platform. System is designed as directfed structure, which means it is not include any storage unit like battery. After validation of system in normal operating conditions, various analyses are performed. As there are 
studies on PV supplied reluctance motors in literature [1819], in this study analysis is performed in two parts. In the first part of study, possible effects of the energy source, which is PV system in this study, are investigated, where in the second part effects of possible to occur at any point of the whole system are examined.

\section{PV System Modelling}

Detailed analysis and study is necessary for an appropriate design of PV systems. Therefore, it should be started from cell level for better understanding. PV panels are formed by connecting photovoltaic cells series and parallel, which are created by semiconductor materials. General structure of a PV cell is given in Fig. 1. [20-22].

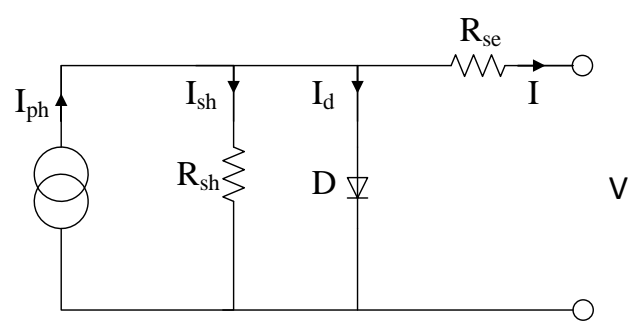

Figure 1. PV cell structure

According to the given equivalent circuit, mathematical model of a PV cell can be described as:

$$
\begin{aligned}
& I=I_{p h}-I_{d}-I_{s h} \\
& I=I_{p h}-I\left[e^{q\left(V+I R_{s e}\right) / k T}-1\right]-\frac{V+I R_{s e}}{R_{s h}}
\end{aligned}
$$

In (2), I shows the current, V represents the terminal voltage, electron charge is shown by q, Boltzmann constant is shown by $\mathrm{k}$ and $\mathrm{T}$ shows ambient temperature, which is in terms of Kelvin.

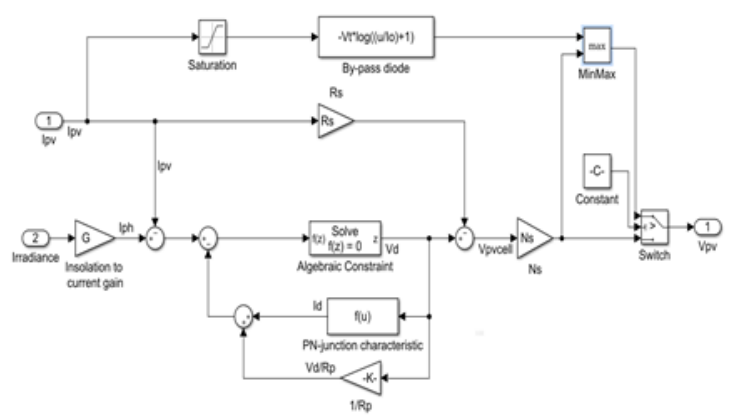

(a)

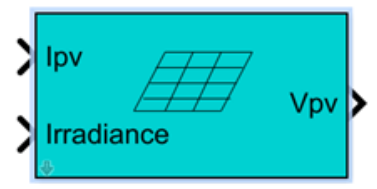

(b)

Figure 2. a) Internal structure and b) block of PV panel
According to the purpose of study, a PV system is designed under MATLAB / Simulink platform. Internal structure and block representation of PV panel is shown in Fig. $2 \mathrm{a}$ and b respectively, where Fig. 3 shows the designed PV system for application.

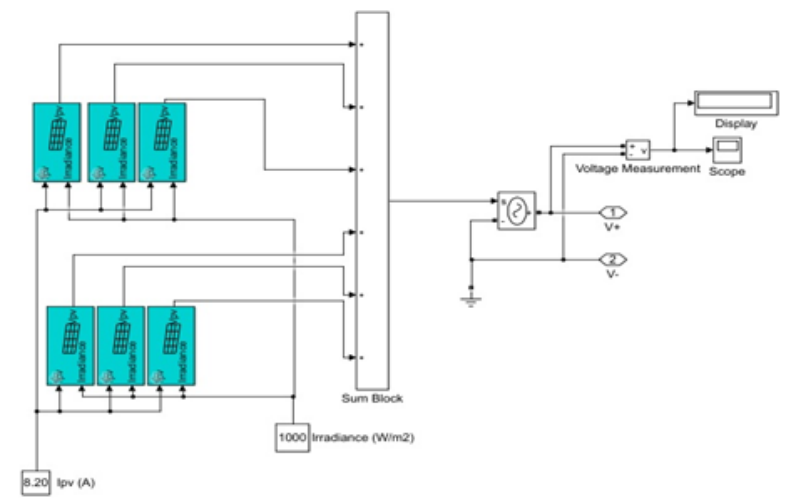

Figure 3. Designed PV system

Each PV panel has properties that shown in Fig. 4.

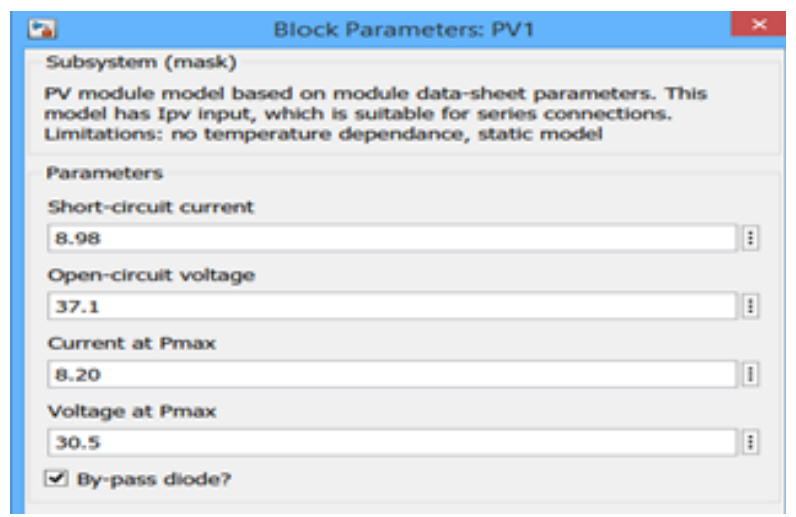

Figure 4. PV panel properties

\section{Switched Reluctance Motor}

Switched Reluctance Motors (SRMs) have advantages such as high-speed operation, high degree of independence between phases, short end-turn, and low inertia [23]. They are increasingly being considered as alternatives to other motor drives in many variable speed applications [24]. Developments for SRMs are not only on better design of the machine itself, but also on advanced control strategies [25]. Because of their valuable advantages, SRMs are being widely used in industrial, agricultural and electric vehicle applications [26-30]. The physical appearance of a SRM is similar to other rotating motors. The construction of 6/4 (6 stator poles, 4 rotor poles) SRM is given in Fig. 5 .

Such motors are defined by ratio of their stator poles to rotor poles. The electromagnetic torque Te that can be obtained from the motor is given as:

$$
T_{e}=\frac{1}{2} i^{2} \frac{d L(\theta, i)}{d \theta}
$$




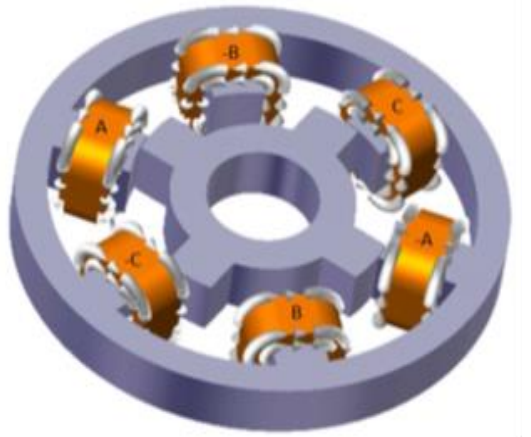

Figure 5. Structure of the 6/4 pole SRM [31]

where $\mathrm{i}$ is the current in amperes and $\theta$ is rotor angle. The torque-speed operating point of an SRM is essentially programmable and determined almost entirely by the control. This is one of the features that makes the SRM an attractive solution for various applications. Similar as other motors, torque is limited by maximum allowed current, and speed by the available terminal voltage, which is illustrated in Fig. 6 [32].

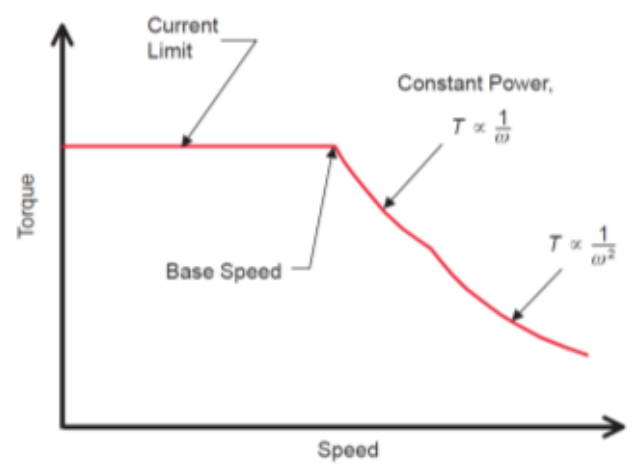

Figure 6. SRM Torque - Speed Characteristics

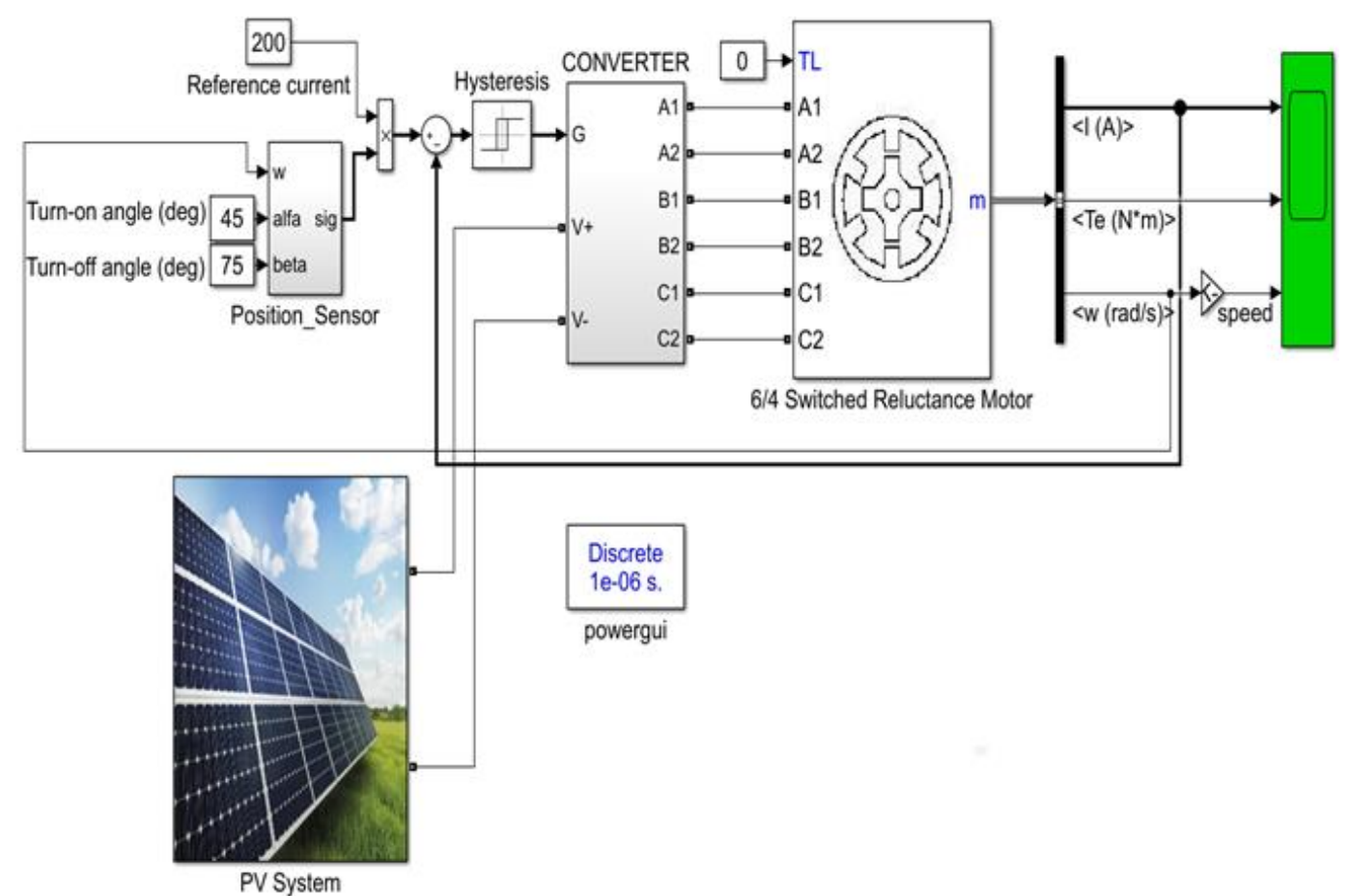

Figure 8. Study system
In this study, system is designed by using a 6/4 SRM. General properties of used SRM are summarized in Fig. 7.

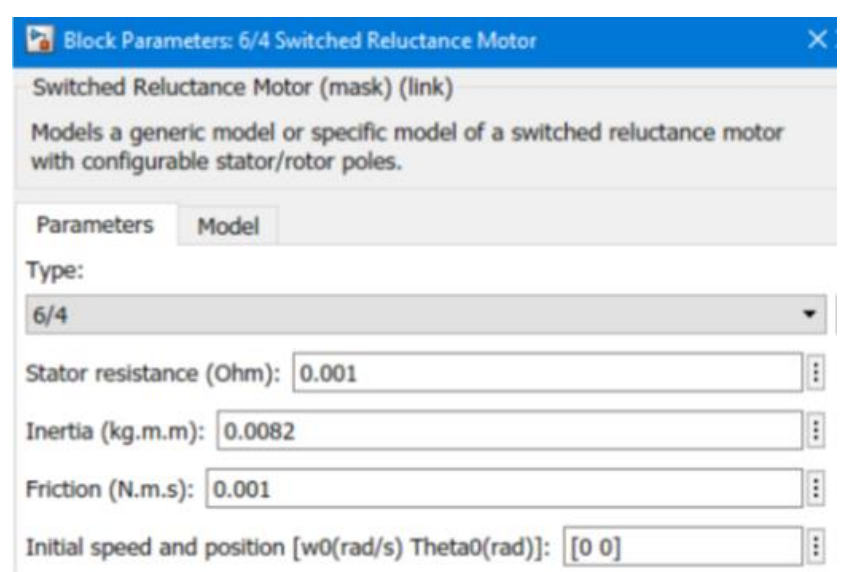

Figure 7. SRM Block Parameters

\section{System Design}

According to the aim of this study, a designed whole system structure is shown in Fig. 8.

The study system is consist of PV system, switched reluctance motor and converter unit as main components. In addition, there are controller blocks and display units as secondary ones [33]. SRM is energized by converter, which is supplied by PV unit. In addition, a simple closed-loop control is used for stability. 


\section{Results and Discussion}

Simulation parameters are adjusted for the system given in Fig. 8 and system is observed during simulation. Two main analyses are performed for detailed observation of system behaviour. These can be classified as observing the effects of PV system and effects of faults.

\subsection{Analysis of PV system effects}

PV system energy generating performance depends on some parameters strictly. Irradiance and shading can be defined as the most important parameters. Different values of irradiance are applied to PV system and effects of such variation are observed by using the graphs. Fig.9 represents the change of irradiation and Fig.10 shows impact of this variation on generated DC voltage from PV system.

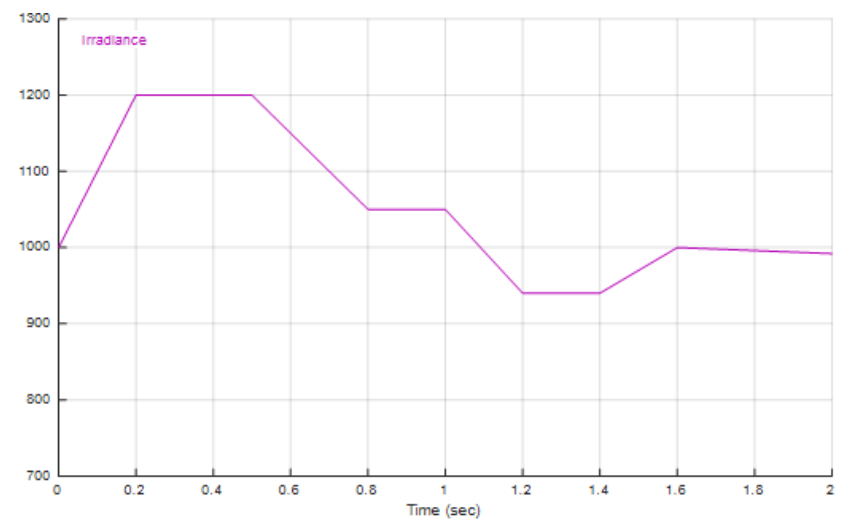

Figure 9. Irradiance change

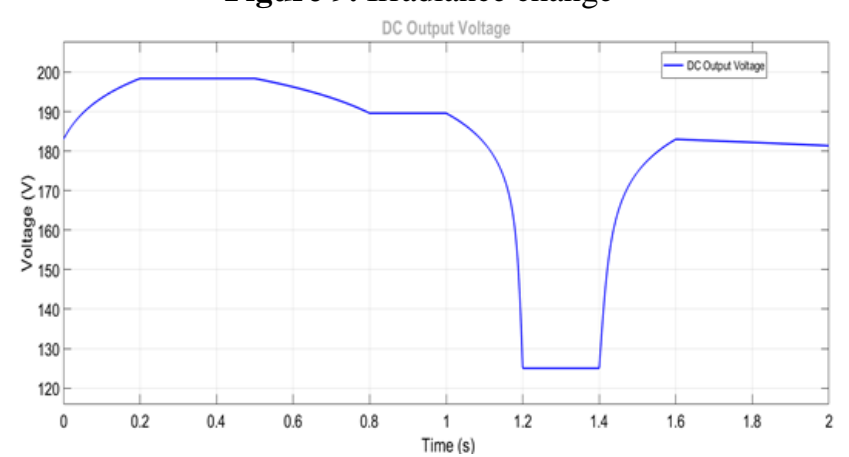

Figure 10. Output DC voltage of PV system

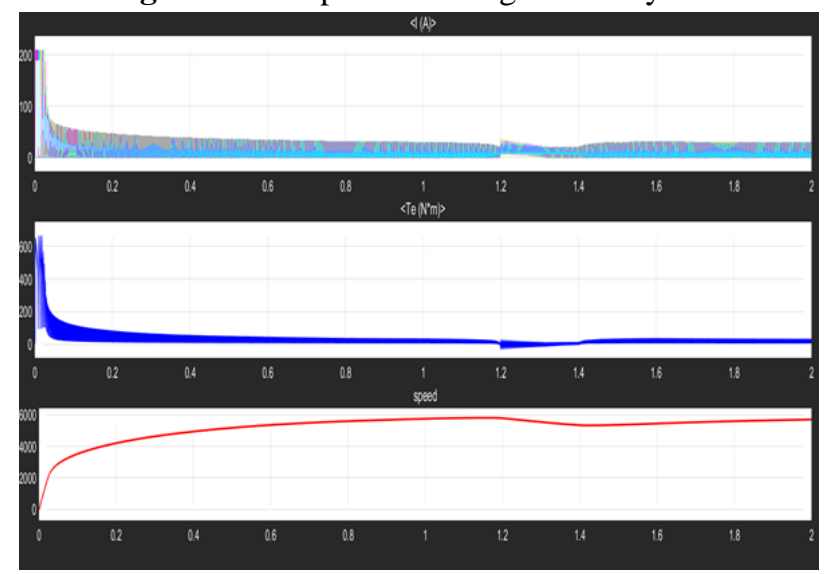

Figure 11. Response of SRM parameters
DC output voltage is applied to converter unit and possible effects of the changes are observed. Fig.11 shows the current, torque and rotor speed graphs respectively.

It is clear from figures that current, torque and speed values affect from change of generating values proportionally, where motor speed is more stable among these parameters.

\subsection{Fault condition analysis}

It is possible to occur any types of faults in a system. In this study, effects of a three phase to ground fault that possible to occur at input terminals of the SRM are investigated. Irradiance was kept constant at $1000 \mathrm{~W} / \mathrm{m}^{2}$ value during the fault condition analysis to observe effects of faults clearly. Fault is applied to system at $0.5^{\text {th }}$ and restored at $1.2^{\text {nd }}$ second. It is supposed that fault was occurred at A1B1C1 terminals of the SRM. Fig.12 shows the current, torque and speed graphs respectively during fault conditions.

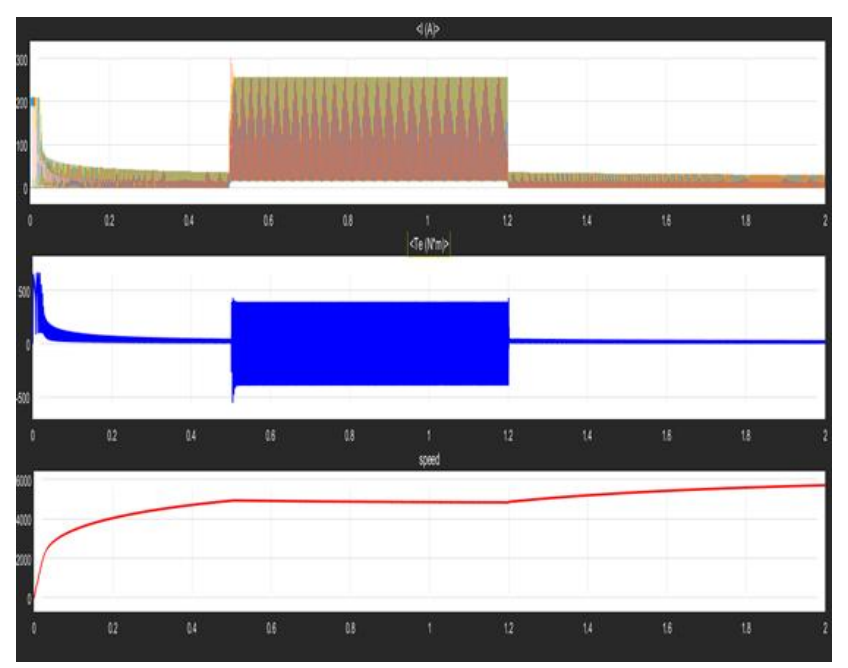

Figure 12. Fault conditions graphs

It is observed from Fig. 12 that current reaches about 10 times of its normal operating value. In addition, a negative torque is occurred during fault. This can be proposed as the most significant inference for the fault condition. On the other hand, speed is relatively stable during fault, as simulation results show. No protection device is added to system for a clear observation of the upper limits of parameters during fault. Therefore, high values are occurred during simulation.

\section{Conclusion}

Increment in electrical energy demand, directs customers to use generated energy at most efficient way. According to this necessity, both sources and loads have to be analysed in detail. If the loads are supplied by the renewable energy sources, appropriate analysis become vital. In this study, a SRM supplied by a PV system is analysed. Analysis is performed in two sections to observe the source and load side effects. Results are discussed by using the graphs that obtained from various points of whole system. Although the 
system is designed as proper as possible, it may be differences at results when compared by an actual installed physical system. According to this disadvantage, authors are in progress of constructing a physical system as a future work for validation of proposed paper. This system will be same as proposed study, which is consist of a PV unit supplying SRM. Analysis results of actual system will be compared with this study and results will be shared by researchers.

\section{Acknowledgment}

This study is an extended and revised version of the paper "Analysis of PV Supplied SRM for Different Operating Conditions" which is presented at ICAT2018 conference.

\section{References}

[1] Farrokhfal, Y. G., Kazhamiaka, F., Rosenberg, C., Keshav, S., 2015, "Optimal Design of Solar PV Farms with Storage", IEEE Transactions on Sustainable Energy, 6 (4), 1586-1593.

[2] Kentli, F., Yilmaz, M., 2015, "Mathematical Modeling of Two-axis Photovoltaic System with Improved Efficiency”, Elektronika ir Elektrotechnika, 21 (4), 4043.

[3] Devassy, S., Singh, B., 2018, "Design and Performance Analysis of Three-Phase Solar PV Integrated UPQC", IEEE Transactions on Industry Applications, 54 (1), 7381.

[4] Hishikawa, Y., et.al, 2018, "Voltage-Dependent Temperature Coefficient of the I-V Curves of Crystalline Silicon Photovoltaic Modules", IEEE Journal of Photovoltaics, 8 (1), 48-53.

[5] Yu, Y., et.al, 2017, "Delta-Connected Cascaded HBridge Multilevel Converters for Large-Scale Photovoltaic Grid Integration”, IEEE Transactions on Industrial Electronics, 64 (11), 8877-8886.

[6] Dong, D., et.al, 2018, "PV Residential Microinverter with Grid-Support Function: Design, Implementation, and Field Testing", IEEE Transactions on Industry Applications, 54 (1), 469-481.

[7] Kumar, S., Singh, B., 2018, "A Multipurpose PV System Integrated to a Three-Phase Distribution System Using an LWDF-Based Approach", IEEE Transactions on Power Electronics, 33 (1), 739-748.

[8] Kim, J.S., Kwon, J. M. Kwon, B.H., 2018, "HighEfficiency Two-Stage Three-Level Grid-Connected Photovoltaic Inverter,' IEEE Transactions on Industrial Electronics, 65 (3), 2368-2377.

[9] Chandel, S.S., Naik, M.N., Chandel, R., 2015, "Review of solar photovoltaic water pumping system technology for irrigation and community drinking water supplies", Renewable and Sustainable Energy Reviews, 49, 10841099.

[10] Gumus, B., Yakut Y. B., 2015, “Analysis of Induction Motor-pump System Supplied by a Photovoltaic Generator for Agricultural Irrigation in Southeastern Anatolian Region of Turkey", J Electr Eng Technol, 10 (3), 777-785.
[11] Zahab, E.E.A., Zaki, A.M., El-sotouhy, M.M., 2017, "Design and control of a standalone PV water pumping system", Journal of Electrical Systems and Information Technology, 4, 322-337.

[12] Yadav, K., et.al, 2015, "Performance comparison of controllers for solar PV water pumping applications", Solar Energy, 119, 195-202.

[13] Kumar, R., Singh, B., 2017, "Single Stage Solar PV Fed Brushless DC Motor Driven Water Pump", IEEE Journal of Emerging and Selected Topics in Power Electronics, 5 (3), 1377-1385.

[14] Boutelhig, A., Bakelli, Y., Hadj Mahammed, I., Hadj Arab, A., 2012, "Performances study of different PV powered DC pump configurations for an optimum energy rating at different heads under the outdoor conditions of a desert area", Energy, 39, 33-39.

[15] Mozaffari Niapour, S.A.KH., Danyali, S., Sharifian, M.B.B., Feyzi, M.R., 2011, "Brushless DC motor drives supplied by PV power system based on Z-source inverter and FL-IC MPPT controller", Energy Conversion and Management, 52, 3043-3059.

[16] Ozdemir, S., Altin, N., Sefa, I., Bal, G., 2014, "PV Supplied Single Stage MPPT Inverter for Induction Motor Actuated Ventilation Systems", ELEKTRONIKA IR ELEKTROTECHNIKA, 20 (5), 116-122.

[17] Hussein, A., Hirasawa, K. Hu, J., 2004, “A robust control method for a PV-supplied DC motor using universal learning networks", Solar Energy, 76, 771780.

[18] Oshaba, A. S., Ali, E. S. Abd Elazim, S. M., 2017, "Speed control of SRM supplied by photovoltaic system via ant colony optimization algorithm", Neural Comput \& Applic, 28, 365-374.

[19] Oshaba, A. S., Ali, E. S. Abd Elazim, S. M., 2015, "MPPT Control Design of PV System Supplied SRM Using BAT Search Algorithm", Sustainable Energy, Grids and Networks, 2, 51-60.

[20] Kocaman, B., Akdağ, M., Efe, S.B., Akdeniz, M., 2017, "Implementation and Performance Analysis of a Hybrid PV-Wind Energy System", International Journal of Engineering and Advanced Technology, 7 (1), 100-104.

[21] Efe, S.B., Cebeci M., 2015, “Artificial Neural Network Based Power Flow Analysis for Micro Grids", Bitlis Eren University Journal of Science and Technology, 5 (1), 42-47.

[22] Efe, S. B., Cebeci, M., Erdoğan, H., Öztürkmen, G., 2015, "A Novel Approach to Power Flow Analysis for Grid Connected Micro Grid”, 13th ICEMES, 11-12 June, 29-32, Oradea, Romania.

[23] Ch, S., Srikanth, M.V., 2014, "Modeling and Analysis of 6/4 Switched Reluctance Motor with Torque Ripple Reduction", International Conference on Advances in Engineering \& Technology, 37.

[24] Husain, T., Elrayyah, A., Sozer, Y., Husain, I., (In Press), "Unified Control for Switched Reluctance Motors for Wide Speed Operation”, IEEE Transactions on Industrial Electronics, DOI 10.1109/TIE.2018.2849993. 
[25] Sovicka, P., Rafajdus, P., Vavrus, V., Zossak, S., 2018, "Current controller with slope compensation for a Switched Reluctance Motor", ELEKTRO, 21-23 May, 1-6, Mikulov, Czech Republic.

[26] Wong, K. F., Cheng, K. W. E., Ho, S. L., 2007, "Simulation of Switched Reluctance Motor Based on a Combination of Circuit-oriented and Signal-oriented Approaches Using Matlab/ SimPowerSystems", Electric Power Components and Systems, 35(2), 205219.

[27] Amarnath, Y., Mishra, A.K., Singh, B., 2018, "SRM driven solar irrigation pumping system utilizing modified dual output SEPIC converter", Engineer Infinite Conference (eTechNxT), 13-14 March, 1-6, India.

[28] Peniak, A., Makarovic, J., Rafajdus, P., et al., 2017, "Design and optimization of switched reluctance motor for electrical vehicles", Electrical Engineering, 99(4), 1393-1401.

[29] Singh, G., Singh, B., 2018, "Control of a 12/8 switched reluctance motor with saturation characteristics for light electric vehicle", Engineer Infinite Conference (eTechNxT), 13-14 March, 1-6, New Delhi, India.

[30] Pindoriya, R. M., Rajpurohit, B. S., Kumar, R., Srivastava, K. N., 2018, "Comparative Analysis of Permanent Magnet Motors and Switched Reluctance Motors Capabilities for Electric and Hybrid Electric Vehicles", Engineer Infinite Conference (eTechNxT), 13-14 March, 1-5, New Delhi, India.

[31] Jambulingam, V., 2016, "Mathematical Modeling and Simulation of Switched Reluctance Motor", International Journal for Research in Applied Science \& Engineering Technology, 4 (4), 441-446.

[32] DiRenzo, M. T., 2000, "Switched Reluctance Motor Control - Basic Operation and Example Using the TMS320F240", Texas Instruments Application Report.

[33] Demir, D., Efe, S. B., 2018, "Analysis of PV Supplied SRM for Different Operating Conditions", 7th International Conference on Advanced Technologies, 28 April-1 May, 269-272, Antalya, Turkey. 